\title{
The functionality of the gastrointestinal microbiome in non-human animals
}

\author{
Irene Hanning ${ }^{1,2^{*}}$ and Sandra Diaz-Sanchez ${ }^{3}$
}

\begin{abstract}
Due to the significance of the microbiome on human health, much of the current data available regarding microbiome functionality is centered on human medicine. For agriculturally important taxa, the functionality of gastrointestinal bacteria has been studied with the primary goals of improving animal health and production performance. With respect to cattle, the digestive functions of bacteria in cattle are unarguably critical to digestion and positively impact production performance. Conversely, some research suggests that the gastrointestinal microbiome in chickens competes with the host for nutrients and produces toxins that can harm the host resulting in decreased growth efficiency. Concerning many other species including reptiles and cetaceans, some cataloging of fecal bacteria has been conducted, but the functionality within the host remains ambiguous. These taxa could provide interesting gastrointestinal insight into functionality and symbiosis considering the extreme feeding regimes (snakes), highly specialized diets (vampire bats), and living environments (polar bears), which warrants further exploration.
\end{abstract}

Keywords: Microbiome, Bacteria, Gastrointestinal tract

\section{Introduction}

In humans, the numbers of bacterial cells outnumber human tissue cells by 10 to 1 . The skin, nasal passages, and gastrointestinal tract are all inhabited with microorganisms, and each location has a specific microbial profile composed of microorganisms best suited to inhabit that niche. Perhaps the most studied of these niches is the gastrointestinal tract (GIT). From Table 1, it is clear that competition, mutualism, and co-habitation all occur within the GIT microbial community as well as provide nutrients and vitamins to the host.

The primary function of the GIT microbes is digestion of ingested food substrates. As shown in Table 2, symbiosis between microbes and their host primarily involves nutrient acquisition. However, beyond digestion, GIT microbes perform other functions that potentially contribute to the overall health status of the host. A well-studied non-digestive function of the gut microbes is the education and regulation of the immune system [1]. The commensal bacteria educate the immune system allowing the host to distinguish

\footnotetext{
* Correspondence: ihanning@utk.edu

${ }^{1}$ College of Genome Sciences and Technology, University of Tennessee, Knoxville, TN, USA

${ }^{2}$ Department of Science, Lincoln International Academy, Managua, Nicaragua Full list of author information is available at the end of the article
}

commensal and pathogenic bacteria. Commensals can also regulate the immune response in the eukaryotic host cells including the inflammatory cascade via the nuclear factor-

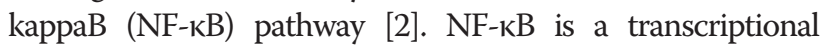
regulator that translocates to the nucleus to induce inflammatory cytokines and recruit immune cells. This process only occurs when NF-kB is unbound from IkB. Commensal bacteria block the NF-kB-IкB disassociation and therefore $\mathrm{NF}-\mathrm{kB}$ cannot enter the nucleus to begin the inflammatory response. Identifying these bacteria and their products could be useful for treating inflammatory-based diseases including inflammatory bowel disease.

Gene regulation by the GIT microbes is not limited to the inflammatory cascade. In fact, Hooper et al. [3] reported that Bacteroides thetaiotaomicron modulates 71 intestinal genes involved in various processes including intestinal maturation and nutrient absorption. More recently, Neufeld and Foster [4] implied that the impact of the GIT microbiome reaches beyond the intestinal tract and even can be linked to brain development. A recent study supports this notion by demonstrating that adult germfree mice show an exaggerated stress response versus conventional counterparts [5]. Additionally, it is also well recognized that many gastrointestinal disorders demonstrate a 
Table 1 Examples of microorganisms found within the gastrointestinal tract of the human lower intestine, the substrates utilized by the bacteria, and products made from the substrates

\begin{tabular}{|c|c|c|c|c|c|}
\hline Domain & Taxa & Nitrogen source & Carbon source & Products made & Metabolic potential \\
\hline \multirow[t]{2}{*}{ Archaea } & $\begin{array}{l}\text { Methanobrevibacter } \\
\text { smithii }\end{array}$ & Ammonium & Carbon dioxide & Methane & $\begin{array}{l}\text { Sulfate reducers } \\
\text { Polysaccharide fermentation }\end{array}$ \\
\hline & Methanosphaera & Ammonium & - & Methane & Sulfate reducers \\
\hline \multirow[t]{17}{*}{ Bacteria } & Actinomyces sp. & - & $\begin{array}{l}\text { D-Glucose, D-mannose, } \\
\text { starch, dextrin } \\
\text { Glycerol }\end{array}$ & $\begin{array}{l}\text { Formate, acetate, succinate, lactate } \\
\text { Various antibiotics }\end{array}$ & $\begin{array}{l}\text { Breakdown and recycle } \\
\text { organic compounds }\end{array}$ \\
\hline & Bacteroides spp. & Ammonium & $\begin{array}{l}\text { Starch, cellulose, xylan, } \\
\text { pectin, dextran } \\
\text { Mucin }\end{array}$ & $\begin{array}{l}\text { Succinate, propionate, acetate, } \\
\text { lactate, formate, and malate }\end{array}$ & $\begin{array}{l}\text { Sugar fermentation } \\
\text { Increased } \mathrm{N} \text { source by } \\
\text { recycling uric acid waste }\end{array}$ \\
\hline & Bifidobacterium & Ammonium & $\begin{array}{l}\text { Glucose, starch, xylan, } \\
\text { pectin, inulin, fructose, } \\
\text { galactose }\end{array}$ & $\begin{array}{l}\text { Acetate, lactate, acetone, thiamine, } \\
\text { folic acid, nicotinic acid, pyridoxine, biotin } \\
\text { Conjugated linoleic acid, vitamins }\end{array}$ & $\begin{array}{l}\text { Vitamin biosynthesis } \\
\text { Carbohydrate fermentation }\end{array}$ \\
\hline & Clostridium & Amino acids & $\begin{array}{l}\text { Glucose, starch, mucin, } \\
\text { hyaluronic acid }\end{array}$ & Acetate, butyrate, acetone, butanol & Proteolytic activity \\
\hline & Desulfovibrio & Ammonium & - & $\begin{array}{l}\text { Hydrogen sulfide } \\
\text { Acetate/ATP }\end{array}$ & Sulfate reducers \\
\hline & Enterococcus & $\begin{array}{l}\text { Collagen, casein, } \\
\text { insulin, Hb, } \\
\text { fibrogen, gelatin }\end{array}$ & Glucose & Lactate & $\begin{array}{l}\text { Lipoprotein lipase inhibitor } \\
\text { Proteolytic activity } \\
\text { Polysaccharolytic activity }\end{array}$ \\
\hline & Escherichia coli & - & Glucose, OS* & $\begin{array}{l}\text { Acetic acid, lactic acid, succinic acid, } \\
\mathrm{CO}_{2}, \mathrm{H}_{2}\end{array}$ & Carbohydrates fermentation \\
\hline & Eubacterium & Amino acids & Glucose, OS* & Lactate, acetate, formate, succinate & $\begin{array}{l}\text { Metabolism of carbohydrates } \\
\text { Lactate-utilizing bacteria }\end{array}$ \\
\hline & Fusobacterium sp. & Amino acids & OS* $^{*}$ & Butyrate & Proteolytic activity \\
\hline & Lactobacillus sp. & Amino acids & Lactose, OS* & Lactate, acetate & $\begin{array}{l}\text { Bile deconjugating activity } \\
\text { Folate production }\end{array}$ \\
\hline & Pediococcus sp. & & Lactose, OS* & Lactate & $\begin{array}{l}\text { Sugar fermentation } \\
\text { Immunomodulatory effects }\end{array}$ \\
\hline & Prevotella sp. & $\begin{array}{l}\text { Dipeptides, } \\
\text { amino acids }\end{array}$ & Pentose, hexose & Acetate, formate, succinate & $\begin{array}{l}\text { Mucin glycoprotein } \\
\text { degraders }\end{array}$ \\
\hline & Propionibacterium sp. & Ammonium & $\begin{array}{l}\text { Lactose } \\
\beta \text {-Galactosidase }\end{array}$ & $\begin{array}{l}\text { Propionic acid } \\
\text { Fatty acids } \\
\text { Vitamin } B_{12} \\
\text { Branched-chain acids } \\
\text { Short-chain fatty acids }\end{array}$ & $\begin{array}{l}\text { Immunomodulatory } \\
\text { effectsLipolysis of glycerides } \\
\text { Catabolism of amino acids }\end{array}$ \\
\hline & Ruminococcus & Ammonium & Various carbohydrates & Formate, lactate, succinate & Mucin degraders \\
\hline & Staphylococcus & - & Lactose, OS* & Lactic acid & $\begin{array}{l}\text { Glucose fermentation } \\
\text { Nitrate reductase and } \\
\text { urease activity }\end{array}$ \\
\hline & Streptococcus sp. & - & $\begin{array}{l}\text { Various sugars, soluble } \\
\text { starch }\end{array}$ & Lactate & Polysacharolytic activity \\
\hline & Veillonella sp. & Amino acids & Lactate & Propionate, acetate & Lactate-utilizing bacteria \\
\hline
\end{tabular}

*OS - Other Solutes

high comorbidity with psychiatric illness [4]. For this reason, emerging work involving germfree mice suggests methods targeting systems outside of the central nervous system are potential treatment options for psychiatric diseases.

A wealth of information regarding the functionality and impact of the gut microbiome on human health has been obtained from clinical studies and experimental models. Currently, studies are applying these methods to non-human animals with bias towards agricultural taxa. Regardless, there are numerous papers available for some species, fewer for others, and no information for some animals. The point of this review is not to provide an exhaustive list of bacterial taxa present in every animal and the functionality of those microbes. Rather, the aim of this review is to point out that some gut microbe functions may be broad and applicable to many animals, while some species may contain unique microbes 
Table 2 Examples of symbiotic interactions between gut bacteria and the host

\begin{tabular}{|c|c|c|c|c|}
\hline Host & Bacteria taxa & Food source & Suggested function & Reference \\
\hline Stinkbug & Ishikawaella capsulata & Plant sap & $\begin{array}{l}\text { Nutrient provision } \\
\text { Amino acid and vitamin synthesis }\end{array}$ & [82] \\
\hline Kissing bug & Rhodococcus rhodnii & Blood-based diets & $\begin{array}{l}\text { Nutrient provision } \\
\text { Growth and development }\end{array}$ & [83] \\
\hline $\begin{array}{l}\text { Honeybee } \\
\text { Leafhopper } \\
\text { Caterpillar }\end{array}$ & Acetobacteraceae & Sugar-based diets & $\begin{array}{l}\text { Oxidize sugars } \\
\text { Acetic acid production }\end{array}$ & {$[84,85]$} \\
\hline Drosophila & $\begin{array}{l}\text { Acetobacter } \\
\text { Lactobacillus }\end{array}$ & Sugar-based diets & Activation of insulinhormone signaling & [86] \\
\hline Goat & Synergistes jonesii & Forage & Metabolize toxins & {$[87,88]$} \\
\hline $\begin{array}{l}\text { Reindeer } \\
\text { SheepElk }\end{array}$ & Eubacterium rangiferina & Forage & Metabolize toxins present in lichen & {$[89,90]$} \\
\hline Rat & $\begin{array}{l}\text { Enterobacteriaceae } \\
\text { Bacteroides }\end{array}$ & Omnivore & Tannin-resistant bacteria & [91] \\
\hline Mice & Helicobacter spp. & Omnivore & $\begin{array}{l}\text { Inducer of CXC chemokine responses in } \\
\text { epithelial cell lines }\end{array}$ & [92] \\
\hline Tammar wallaby & $\begin{array}{l}\text { Unique clades of Lachnospiraceae, } \\
\text { Bacteroides, Gammaproteobacteria }\end{array}$ & Herbivore & Plant biomass conversion & [93] \\
\hline Flying squirrel & Dominated by Firmicutes & Herbivore & $\begin{array}{l}\text { Degradation of carbohydrates } \\
\text { Metabolism of proteins } \\
\text { Synthesis of vitamins }\end{array}$ & [94] \\
\hline Giant panda & Clostridium I and XIVa & Bamboo & Cellulolytic and hemicellulolytic activities & [95] \\
\hline Zebra & Lactobacillus equigenerosi & Herbivore & Plant fermentation & [96] \\
\hline Horse & Weissella confusa/cibaria & & & \\
\hline Ostrich & $\begin{array}{l}\text { Fibrobacter succinogenes } \\
\text { Fibrobacter } \\
\text { intestinalis }\end{array}$ & Herbivore & Fibrolitic activity & [97] \\
\hline Grass carp & $\begin{array}{l}\text { Anoxybacillus } \\
\text { Leuconostoc } \\
\text { Clostridium } \\
\text { Actinomyces } \\
\text { Citrobacter } \\
\text { Aeromonas }\end{array}$ & Herbivore & Cellulolytic activity & [98] \\
\hline Surgeon fish & Epulopiscium fishelsoni & Herbivore & Digestion of herbs and detritus & [99] \\
\hline Iguanas & Archaebacteria (Methanogens) & Herbivore & Fermentation & [100] \\
\hline American bullfrog tadpoles & $\begin{array}{l}\text { Edwardsiella tarda } \\
\text { Clostridium }\end{array}$ & Herbivore & Carbohydrate fermentation & [101] \\
\hline
\end{tabular}

performing unique functions and to use a few animal species to demonstrate this idea. Deciphering and defining the functionality of the gut microbes can be addressed using various methods and observations.

\section{Changes, disruption, and absence of the normal microbiome}

Assessing and determining the functionality of microbes is not an easy task. Numerous experiments have been undertaken to understand the function of the gut microbiome in different species. These approaches include analyzing animals reared in sterile environments lacking any gut microbiome and transplanting microbiome from one animal to another. Disruptions to the microbiome such as fasting or gastrointestinal infection also provide insight regarding functionality of the commensals. Furthermore, these types of comparisons may be made to enhance the understanding of the symbiotic balance.

\section{Germfree}

One approach to determine functionality of microbiomes is to compare sets of conventional animals to those without microbiomes. These so-called germfree animals have been documented as early as 1895 by Nuttall and Theirfelder [6] who intended to prove that microbes were not needed for life and were actually harmful by creating germfree guinea pigs. Other experiments including one conducted by Cosendy and Wollman also intended to 
demonstrate that animals could live without microbes and utilized "germfree" chickens to test their hypothesis $[7,8]$.

It is clear from early experiments and the newest information that higher organisms can exist without microbes. However, drastic differences are noted in germfree animals. Germfree sea bass (Centropristis striata) had reduced mucosal linings due to an absence of microbial stimulation of mucosa production [9]. The intestinal villi of the germfree dog are of the same length as the normal counterpart but are thinner with pointer tips [10]. The lamina propria of germfree mice has a sparse stroma, with few lymphocytes and macrophages, and the Peyer's patches are smaller. In all germfree animals studied, the turnover rate of intestinal epithelium was decreased. These histological changes in the intestine are the result of a reduced interaction with the bacteria that stimulate the immune system and histological development [11].

In addition to histological changes in the intestine, other organs and physiological changes have been noted. The germfree rat has a smaller heart and a cecum that is four to six times larger than rats with normal microbiomes [12]. This change has been explained by an accumulation of substances normally degraded by the microbiome and histological changes of the cecum epithelial cells [13]. In germfree chicks, the body temperature is slightly higher than that of chicks with normal flora [14]. These experiments have demonstrated the complex role that microbiomes play in host development, not only in the gastrointestinal systems but in other organs as well.

\section{Fasting}

That fasting tends to shift the GIT bacteria populations has been demonstrated in many animals including mice, alligators, pythons, and chickens [15-18]. Furthermore, a feeding/fasting cycle promotes diversity of the microbiome [18]. During fasting, the lack of nutrient availability impacts the intestinal mucin layer, as bacteria with the ability to utilize mucin will degrade it for a nutrient source [19]. Hence, when the host does not provide nutrients to the commensals, the commensals will start to consume the host. This may be because fasting suppresses the host antibacterial defenses [20, 21]. Interestingly, even though the protective barrier of mucin is decreased, bacterial translocation across the epithelia may not increase [21].

Like fasting, hibernation also affects on the microbiome populations. Sonoyama et al. [22] reported that Clostridium predominated in both active and hibernating hamsters and populations of Akkermansia muciniphila, a mucin degrader, increased in fasting but not during hibernation. An early study of ground squirrels using culturing methods found that there was some reduction in total numbers of viable bacteria in the cecum during hibernation, but that the profile of the microbiota remained stable [23]. However, a more recent study using deep-sequencing methods found that the population profiles did shift. Specifically, hibernation increased populations of Bacteroidetes and Verrucomicrobia, capable of degrading mucin, and reduced populations of Firmicutes, which prefer polysaccharides [24].

Hibernating animals typically have a hypoactive immune system. Because a hypoactive immune system can lead to aberrant bacterial growth and inflammation, understanding how the immune system regulates bacterial populations during hibernation is of great interest. In their studies using hibernating leopard frogs, Gossling et al. [25] tested several hypotheses to understand this regulation, including unique circulating antimicrobials and antibody production, but no conclusive results were able to answer the question. More recently, Dill-McFarland [26] reported that toll-like receptors 4 and 5 (TLR4 and TLR5) are modulated in hibernating ground squirrels. These receptors recognize microbial products and initiate host immune responses focused on inflammation.

Compared with other animal taxa, there is little information about the gastrointestinal microbiome found in reptiles, many of which practice an extreme feeding/fasting cycle. Snakes are very interesting animals because many species have extreme periods of fasting with a time span as long as 1 year between meals [27]. In addition, all snakes ingest and rapidly digest whole prey. These two facts suggest that snakes must be very efficient at nutrient uptake, and this would hold true for the microbiome as well. These extreme feeding regimes in the snake raise the question of whether the microbiome impact on nutrient uptake is more dramatic in the snake or has any affect at all. Peterson et al. [28] aimed to answer this question using African house snakes where the snakes were repeatedly given oral dosages of antibiotics (treatment) or sterile water (control) prior to consuming sterilized mice. Intestinal samples were obtained non-lethally each time prior to feeding and sequencing of these samples was conducted. No differences in energy densities of expelled mice or feces and uric acid as determined by bomb calorimetry were reported. However, the bacteria populations present in the intestinal samples were very different between the two groups. From the data, the authors concluded that the bacterial microbiome had no significant impact on nutrient acquisition.

\section{Disruptions and changes}

Disruptions in the normal patterns of host microbiome may occur for a variety of reasons. Changes in diet, antibiotic intake, or colonization by pathogens have all been demonstrated to result in a shift in the microbiome populations [29]. In some cases, this shift results in negative health consequences, because the immune 
system maintains a constant production of antibodies aimed at the normal microbiome pattern that must be adjusted to fit the new bacterial population, and this can be costly in terms of energy expenditures.

Normal changes in the microbiome occur overtime and can be related to factors such as age. For example, the chicken GIT is sterile at hatch but quickly colonized by aerobic Proteobacteria and after 12 days is dominated by anaerobic Firmicutes. Initially, the Proteobacteria stimulate the histological maturation of the GIT and provide an ideal environment for the Firmicutes. The Proteobacteria do well in the immature GIT but are poor competitors and are outcompeted after a mature and anaerobic gut environment is established. The succession of bacteria is also dependent on nutrition and gut bacteria population selection, and establishment can also be selected by feeding specific foods. This was demonstrated in rabbits fed only milk for the first 42 days of life. These animals did not possess cellulolytic bacteria in the cecum and could not digest plant matter [30].

Metamorphosis and the impacts of the process on intestinal populations have been demonstrated in frogs and toads by comparing gut microbes in tadpoles versus adult forms [31]. Tadpoles have more diversity and a microbiome similar to fish, while frog GIT profiles resemble amniotes. The differences are attributed to food preferences and GIT structure. Like amphibians, metamorphosis of the sea lamprey and mosquito results in GIT rearrangement and feeding preferences [32, 33]. In both species, the microbiome in the adult is substantially less diverse than in the young. Specific to the lamprey, the sanguivore form apparently selects for the Aeromonads because this population of bacteria increases from $4 \%$ in the young to $84 \%$ in the parasitic fish. Analysis of these Aeromonads found all species and strains were hemolytic. Like other sanguivores, Aeromonas hydrophila was consistently isolated from fecal samples of vampire bats and is thought to be necessary for the digestion of blood [34]. The authors also suggested that acquisition of the bacterium by nursing the young through coprophagy is essential in order to transition to the sanguivore lifestyle.

\section{Longevity and fecundity}

Commensals of the microbiome can be classified as obligate or facultative. The obligate bacteria often have a reduced genome and are dependent on the host and the microbial community for nutrients and other essential compounds. As an example, Lactobacillus johnsonii codes for amino acid proteases, peptidases, and phosphotransferase transporters but not for genes necessary for biosynthetic pathways. In addition, $L$. johnsonii contains all of the genes necessary for the synthesis of pyrimidines but not for the synthesis of purines, and therefore, the bacterium must acquire amino acids, peptides, and purine nucleotides as secondary metabolites from other microorganisms or from the human host [35]. Since obligate microbes, like $L$. johnsonii, are dependent on the host for survival, promoting the fitness of the host is advantageous to the symbionts.

In humans, promoting longevity is a leading research focus, and how the microbiome can modulate longevity is of great interest. This research area is just beginning and some animal models have demonstrated a link between the gut microbiome and longevity. It was reported that feeding wild-type soil bacteria Bacillus spp. to Caenorhabditis elegans versus the typical Escherichia coli lab strain increases longevity [36]. In Drosophila, infection with an avirulent Wolbachia extends life-span [37]. The mechanisms by which bacteria can extend life-span have been attributed to host gene regulation of immune factors and cell proliferation and availability of key vitamins and co-factors produced by the microbiome [38, 39].

Unlike humans, the goal in rearing agricultural taxa is not longevity but rather to hasten maturity. Hastening maturation and achieving the shortest rearing period possible to obtain harvest weight reduces production time and, in turn, drives down costs. The rearing period of farm-raised Atlantic salmon has been cut in half by genetic modification. A growth hormone-regulating gene from the Pacific Chinook and promoter from the ocean pout were added to the genome of the Atlantic salmon. This modification allows the fish to grow year-round and achieve market weight in half the time (16 months versus 3 years).

Many agricultural animals do not need to be genetically modified to achieve accelerated growth rate because growth promotion can be obtained through modifying the intestinal microbiome. Delivering probiotic cultures to animals hastens the histological development of the intestinal tract $[40,41]$. The mature GIT improves nutrient uptake and increases the growth rate of the animal [40]. Studies in the pig indicate that careful selection of probiotic bacteria is crucial because the bacterial species colonizing the intestinal tract can have a lifelong impact on intestinal health. Shirkey et al. [42] reported differences in the gut histology and immune marker responses dependent on which bacteria initially colonized the gut of the pigs. The group reported that single-strain cultures affected regions of the intestines differently than mixed cultures, and it therefore appears that microbial diversity facilitates healthy maturation of the entire intestinal tract.

It has been argued that the effect of improved growth rate in probiotic-treated animals is temporal, and nontreated counterparts eventually meet the same weight [43]. In fact, some studies have demonstrated that microbes have an overall deleterious impact on growth 
production in chickens and pigs, where gut metabolism accounts for $20-36 \%$ of the whole body energy expenditure [44-46]. This is due to host-microbiota competition for nutrients, which results in a net energy loss and decreased growth rate. Further, the microbiome stimulates the production of IgA, IgG, and mucin secretion that can cost the animal several hundred grams of protein over a lifetime that is not utilized for growth [47]. Considering the rearing period of a broiler chicken (42 days) and the average final weight (3000 g), a loss of several hundred grams can be significant. Shifts in the gut microbiome may also initiate a costly energy production because different antibodies must be produced [48]. Sub-therapeutic doses of antibiotics delivered in feed can achieve a stable bacterial and antibody production resulting in an increased growth rate and hence their use in some animal production. Regardless of the energy that the microbiome may cost the animal, it is clear that germfree production of agriculture animals to improve production performance is not a realistic practice.

The impact of the microbiome on host fecundity has been demonstrated in a number of insects. Insect studies suggest that oviposition rates are dictated by the volatile compounds produced by the fecal bacteria, and these compounds are olfactory stimulants that are used as positive cues [49]. Similarly, the volatile compounds produced by the gut microbiome can also promote mating aggregations [50]. Rosengaus et al. [51] showed that termites treated with Rifampin reduced the number of nitrogen-fixing bacteria and may have resulted in a loss of amino acids required for oviposition.

In higher animals, there is some evidence of amino acid provisions supplied by the microbiome and an impact on reproduction [52]. But these and other connections between host reproduction and the microbiome are more difficult to discern due to the complexity of higher animal systems. Studies in cows and pigs demonstrate a shift in the GIT microbes during the gestation period, and thesis shifts were inferred to be for fat deposition to support the developing fetus and milk production [53, 54]. It has been suggested that changes in hormones and immune factors during gestation cause subsequent modifications in the microbiome profiles. Thus, it appears that host factors may modulate the microbiome in order to facilitate some physiological needs of reproduction.

\section{Health and disease}

Of all the functions that gastrointestinal bacteria perform, promoting health and preventing disease are likely the most studied. Commensal organisms prevent pathogens from colonizing the host by producing antimicrobial substances (organic acids, bacteriocins) and competing for nutrients and spaces [55]. Pathogens must compete with the commensal bacteria and devise methods to promote infection. For example, Salmonella typhimurium induces the inflammatory pathway to reduce the microbial population [56]. Inflammation also provides reactive oxygen species that react with thiosulfate to produce tetrathionate [57]. Tetrathionate can be used by Salmonella in the respiratory pathway, and the presence of this compound affords a selective advantage for the pathogen.

In the health promotion framework, the concept of probiotic administration has been extensively explored in numerous taxa to explore the efficacy and benefits of these beneficial cultures. Some have sought probiotic cultures from unusual sources that have unique abilities and might be applied to non-host species. Diaz et al. [58] conducted experiments to determine the ability of the Lactobacilli spp. isolated from dolphins to inhibit pathogenic growth and stimulate tumor necrosis factor (TNF) production in human monocytoid cells. The authors concluded that many of the strains possessed beneficial probiotic abilities, but whether or not these abilities were active during colonization of the dolphin is still unknown.

Understanding the mechanisms of pathogenesis and how commensal microbes defend the host can lead to therapeutic methods. Conversely, studying the relationship and identification of pathogens can lead to unique methods for control of certain pest insects. One specific example took advantage of ice nucleation to control the mulberry pyralid (Glyphodes pyloalis). Ice nucleation refers to the process where insects enhance their supercooling capacity during the winter by eliminating endogenous ice nucleators, accumulating low-molecularweight polyols and sugars, and synthesizing hemolymph antifreeze proteins to prevent the formation of internal ice crystals that can pierce and damage cells and tissues. In the mulberry pyralid, active bacteria within the gut are known to increase the supercooling points and reduce cold hardiness by expressing an ice nucleation gene. Wantbe et al. [59] colonized the gut of the mulberry pyralid with a strain of Enterobacter cloacae, having a transformed ice nucleation gene that led to increased mortality of the insect. A second example involves the medically important triatomine bug that may be colonized by the parasite Trypanosoma cruzi. Triatomine bugs were colonized with the mutualistic bacterium Rhodococcus rhodnii that was genetically transformed to express an antitrypanosomal peptide effectively preventing colonization and development of the parasite population in the gut of the insect [60].

\section{Functional dependence for nutrients and digestion}

Many herbivores do not produce endogenous cellulases, hemicellulases, and pectinases and as such are dependent on the gut microbiomes for digestion of plant 
material. Cranial fermenters utilize a rumen in the foregut for fermentation, while caudal fermenters possess a cecum in the large intestines. The location of fermentation has an impact on animal physiology and nutrition. Both types are dependent on the fermentative microbes to extract energy from cellulose. However, unlike caudal fermenters, cranial fermenters cannot utilize hexose sources directly, and these sugars are instead converted to volatile fatty acids in the rumen. Since amino acid absorption takes place in the small intestines, cranial fermenters can utilize the microbes themselves as a source of protein. In fact, in cows, bacterial biomass provides about half the protein requirement for the animal [61]. Conversely, microbial proteins are lost in caudal fermenters because the cecum is located after the small intestines, where amino acids are absorbed. The dependence of the cranial fermenters on microorganisms for digestion is clear when considering the inability to produce healthy germfree adult cows. Germfree calves have been produced and can be sustained for a short time because they feed on sterilized milk, yet adults are nearly impossible to sustain due to the reliance on microorganisms for symbiotic digestion of plant materials.

Although rabbits are caudal fermenters, they can still obtain microbial proteins through cecotrophy. This process is a 2-cycle approach where the first ingestion of plant material is fermented by bacteria in the cecum. Pellets are excreted and ingested and proteins of microbial sources in the pellets are absorbed in the small intestines. Cecotrophes produce two chemically distinct types of feces in order to maximize the extraction of essential nutrients, amino acids, and vitamins from the plants. The impact on the microbial community and the animal due to cecotrophy has been documented. Rabbits prevented from coprophagy have sterile stomachs and may suffer from malnutrition [62].

Marsupial foregut fermenters, or macropods, are cranial fermenters like cows but with anatomical differences (the cow has a four-chambered stomach and the kangaroo only one). Both animals also regurgitate and re-chew food. Rumination in the cow is the key to the digestion process as resalivation of regurgitated feed provides buffers for the rumen that maintain the $\mathrm{pH}$ required by the microbiome. In kangaroos, there is little evidence that the regurgitation of food, termed merycism in macropods, is necessary since they eat very slowly and masticate well [63]. Unlike cattle and sheep, kangaroo digestion releases virtually no methane gas during exhalation accomplished by unique microbes converting the hydrogen by-product of fermentation into acetate. These microbes are being sought for use in cattle production to reduce greenhouse gas emission, and some unique microbes of the macropod microbiome have been identified. Pope and co-workers [64] identified bacterial populations present in the tammar wallaby and reported that at the phylum level the Firmicutes and Bacteroides were the dominant taxa. The group also noted that the majority of the phylotypes were unique and only distantly related to cultured bacteria. Evans et al. [65] reported unidentified methanogens and archaea isolated from the tammar wallaby that were related to bacteria isolated from GITs. The function of these bacteria has not been determined, but genes associated with cell aggregation were identified which they suggested were advantageous for digestion because aggregation facilitates plant biomass digestion.

Many other animals also depend on the gastrointestinal bacteria to digest cellulose. For example, the cellulolytic bacterium Teredinibacter turnerae colonizes the Deshayes gland of shipworms, a common group of clams that bore into wooden ships and piers. This bacterium produces cellulases that degrade the wood the clams ingest [66]. The bacterium also fixes nitrogen providing a useable source of nitrogen to the shipworm. The symbiotic dependence for nutrient acquisition in this relationship lacks data because sequencing of the T. turnerae genome revealed no deletions in essential genes implying that the bacterium can survive outside the shipworm host [67]. Unlike shipworms, there is plenty of evidence showing that many terrestrial termites are highly dependent on their endosymbionts [68]. In fact, some species die of starvation when the gut microbiome is eradicated with antibiotics [69]. Behaviors including proctodeal feeding suggest termites are aware of their dependence on the microbiome and practice the behavior to ensure transmission of a uniform microbiome among the individuals [70].

A recent study of the American alligator revealed the impacts of evolution on the microbiome for digestive dependence [17]. The authors found a high proportion of Fusobacterium in the alligator gut, which is unusual because Firmicutes or Bacteroidetes typically dominate the gut bacteria populations. For this reason, the authors suggest Fusobacterium performs functional roles including development of the digestive organs and nutrient acquisition in the alligator. Furthermore, given that the basal position of Fusobacterium on the evolutionary tree and that the American alligator is the least evolved of nearly all animals, the authors suggest that Fusobacterium were dominant gut microbes in some prehistoric animals.

\section{Adaptation to environmental extremes}

Marine sponges and tubeworms inhabit a wide distribution of marine environments, but many can be found in locations near hydrothermal vents with pressures of 400 bar $(395 \mathrm{~atm})$ and water temperatures up to $60{ }^{\circ} \mathrm{C}$. This environment may also have an acidic $\mathrm{pH}$ and is rich in chemicals emitted from the vents including sulfide, 
hydrogen, and methane. The sponge or tubeworm absorbs chemicals, and microbial symbionts process the chemicals into organic molecules the host needs, while the bacteria gain a stable habitat. The dependence of the tubeworm and sponges on their symbiotic chemoautotrophic bacteria for nutrients has been well established [71]. Studies have confirmed the microbiome of these invertebrates is distinct from the surrounding water [72], and evidence of vertical transmission of endosymbionts exists [73]. Together, data from studies of these animals point to an adaptation of the host to an otherwise uninhabitable environment partly facilitated by the symbiotic bacteria.

Many marine mammals also inhabit extreme environments such as the polar arctic. To date, the few studies examining the gut microbiome of marine mammals living in these extreme environments have identified and cataloged bacteria, but little functionality of these bacteria has been explored. Glad et al. [74] identified the bacteria present in 10 different samples obtained from the rectums of polar bears (Ursus maritimus; note: polar bears are considered marine mammals and protected as such under marine mammal laws). Ogawa et al. [75] used cloning techniques to characterize gut bacteria in three different minke whales (Balaenoptera acutorostrata). These studied animals are carnivorous, feeding primarily on fish (minke whales) or seals (polar bears), and thus, the identification of bacteria including Bacteroidetes and Firmicutes is not surprising. Although primarily characteristic in nature, the distribution and abundance of the bacteria in these studies may provide clues for functionality. Firmicutes were the dominant taxa in nearly all the samples, and these bacteria have an increased capacity to stimulate host energy storage over other phyla [76]. These animals rely heavily on fat deposition for survival not only for energy storage but also to maintain body temperature. Thus, it is possible that some animals living in the polar extremes rely on their gut microbes to facilitate efficient fat storage needed for survival.

\section{Functionality revelations by comparative analysis}

Intra-species comparisons of the metagenomes of individuals have revealed the functionality of some digestive communities. Qu et al. [77] used a chicken model to show that even though two individuals may have marked differences in microbiomes, the functional metagenome can be the same. They concluded that in their samples, bacterial taxa replaced other taxa without changing the overall function of the microbiome. Conversely, comparison of rumen samples among individuals showed marked differences in microbiomes that did result in differences in the overall functional microbiome [78]. The conflicting results in the two studies may be attributed to diet and digestive tract physiology.
Comparing phylogenetically divergent animals can also provide a better understanding of how microbiomes function and evolve and are shaped by factors such as diet and physiology. Although the cow and termite are both heavily dependent on bacteria for celluloytic digestion, diet was the main factor that shaped the microbiomes in these animals [78]. Comparison of the cow and hoatzin (a foregut fermenting bird) revealed that very similar microbial compositions and organ digestive functions dictated microbial profiles rather than phylogeny [79]. Interestingly, comparative genomic studies have demonstrated that the bacterial profile in swine and humans are similar and harbor many of the same phylogenetic groups primarily due to the similar gastrointestinal systems [80]. However, comparative metagenomic analysis of the pig, chicken ceca, cow rumen, and human fecal microbiomes showed that the metagenomes of the pig aligned more closely with the cow and chicken than with the human microbiome [81]. The results imply that agricultural taxa possess bacterial metagenomes that have been selected as a result of a very consistent and narrowly defined diet and rearing environment.

\section{Conclusions}

Studies of the gastrointestinal tract of animals have produced a wealth of information and revealed that populations are contingent on a number of factors including diet, habitat, and taxonomy. Although animals may be very different evolutionarily, they may have very similar microbes based on specific factors. Mosquitoes, leeches, sea lamprey, and bats are all sanguivores but have very different habitats and are quite distant on the evolutionary tree. However, the digestive tract is dominated by Aeromonas spp. in all these animals and is most likely for digestion of blood. Similarly, herbivorous fish, cows, and insect termites have similar cellulolytic microbiota with cows.

Some bacteria species are present in the microbiomes of a wide variety of animal taxa. Conversely, there are unique microbes performing unique functions in a very narrow group or species. Identifying, harvesting, and transplanting these microbes to other animal systems have been sought to perform the same function in nonhost species. This concept has been applied to the use of kangaroo intestinal bacteria in the cattle rumen to reduce methane emission. Like other cross-species transplants, application of kangaroo bacteria in the cattle has failed even though the animal system is quite similar. Even at the breed level, it appears that genetics has a large impact on microbial population and function. Transplants of the same microbe into two different chicken breeds resulted in faster weight gain in only one of the breeds. Bacterial transplant failure may be the 
result of host specificity obtained through co-evolution. This co-evolution has selected the functional roles of the microbiome in a specific host. Thus, understanding the functional roles of microbes and how they interact with the host might further our ability to successfully transplant microbes.

\section{Competing interests}

The authors declare that they have no competing interests.

\section{Authors' contributions}

SD and IH conceived, outlined, wrote, revised, and finalized the manuscript. Both authors read and approved the final manuscript.

\section{Acknowledgements}

This work was supported by the HATCH funds awarded to Dr. Hanning.

\section{Author details}

${ }^{1}$ College of Genome Sciences and Technology, University of Tennessee, Knoxville, TN, USA. ${ }^{2}$ Department of Science, Lincoln International Academy, Managua, Nicaragua. ${ }^{3}$ Department of Food Science and Technology, University of Tennessee, Knoxville, TN, USA.

Received: 16 January 2015 Accepted: 28 September 2015

Published online: 10 November 2015

\section{References}

1. Kau AL, Ahern PP, Griffin NW, Goodman AL, Gordon Jl. Human nutrition, the gut microbiome and the immune system. Nature. 2011:474(7351):327-336.

2. Neish AS, Gewirtz A, Zeng H, Young A, Hobert M, Karmali V, et al. Prokaryotic regulation of epithelial responses by inhibition of IkB-a ubiquitination. Science. 2000:289:1560-3.

3. Hooper LV, Wong MH, Thelin A, Hansson L, Falk PG, Gordon Jl. Molecular analysis of commensal host-microbial relationships in the intestine. Science. 2001;291:881-4.

4. Neufeld KA, Foster JA. Effects of gut microbiota on the brain: implications for psychiatry. J Psychiatry Neurosci. 2009;34:230-1.

5. O'Mahony SM, Marchesi JR, Scully P, Codling C, Ceolho AM, Quigley EM, et al. Early life stress alters behavior, immunity, and microbiota in rats: implications for irritable bowel syndrome and psychiatric illnesses. Biol Psychiatry. 2009;65:263-7

6. Nuttall HF, Thierfelder H. Thierisches leben ohne bacterien im verdauungskanal. Hoppe-Seyler's Z Physiol Chem. 1895;21:109-21.

7. Cosendy M. Experiences sur la vie sans microbes. Ann Inst Pasteur. 1912;26:106-37.

8. Cosendy M, Wollman E. Experiences sur la vie sans microbes. Elevage aseptique de cobayes. Comptes Rendus. 1914;158:1283-4.

9. Rekecki A, Dierckens K, Laureau S, Boon N, Bossier P, Van den broeck W. Effects of germ-free rearing environment on larval sea bass (Dicentrarchus labrax L.). Aquaculture. 2009;293:8-15.

10. Heneghan JB. Enterocyte kinetics, mucosal surface area and mucus in gnotobiotes. In: Fliedner T, Heit H, Niethammer D, Pflieger H, editors. Clinical and Experimental Gnotobiotics. New York: Gustav Fisher; 1979. p. 19-27.

11. Fasano A, Shea-donoghue T. Mechanisms of disease: the role of intestinal barrier function in the pathogenesis of gastrointestinal autoimmune diseases. Nat Clin Pract Gastroenterol Hepatol. 2005:2:416-22.

12. Gordon HA, Wostmann BS, Bruckner-Kardoss E. Effects of microbial flora on cardiac outputs and other elements of blood circulation. Proc Soc Exp Biol Med. 1963;114:301-4

13. Ishikawa K, Satoh Y, Oomori Y, Yamano M, Matsuda M, Ono K. Influence of conventionalization on cecal wall structure of germ-free Wistar rats: quantitative light and qualitative electron microscopic observations anatomy and embryology. Anat Embryol. 1989;180:191-8.

14. Harrison GF, Hewitt D. The influence of the conventional microbiota on the body temperature of the chicken. Br Poult Sci. 1978;19:273-5.

15. Thompson K, Burkholder K, Patterson J, Applegate TJ. Microbial ecology shifts in the ileum of broilers during feed withdrawal and dietary manipulations. Poult Sci. 2008;87:1624-32.

16. Costello EK, Gordon Jl, Secor SM, Knight R. Postpandrial remodeling of the gut microbiota in Burmese pythons. ISME J. 2010;4:1375-85.
17. Keenan SW, Engel AS, Elsey RM. The alligator gut microbiome and implications for archosaur symbioses. Scientific Rep. 2013;3.

18. Zarrinpar A, Chaix A, Yooseph S, Panda S. Diet and feeding pattern affect the diurnal dynamics of the gut microbiome. Cell Metabolism. 2014;20:1006-17

19. Derrien M, Vaughan EE, Plugge CM, de Vos WM. Akkermansia muciniphila gen. nov., sp. nov., a human intestinal mucin-degrading bacterium. Int J Syst Evol Microbiol. 2004;54:1469-76.

20. Faggioni R, Feingold KR, Grunfeld C. Leptin regulation of the immune response and the immunodeficiency of malnutrition. The FASEB J. 2001;21:2565-71.

21. Choudry MA, Fazal N, Goto M, Gamelli RL, Sayeed MM. Gut-associated lymphoid T-cell suppression enhances bacterial translocation in alcohol and burn injury. Am J Physiol Gastrointest Liver Physiol. 2002;282:937-47.

22. Sonoyama K, Fujiwara R, Takemura N, Ogasawara T, Watanabe J, Ito H, et al. Response of gut microbiota to fasting and hibernation in Syrian hamsters. J Appl Environ Microbiol. 2009;75:6451-6.

23. Barnes EM, Burton GC. The effect of hibernation on the caecal flora of the thirteen-lined ground squirrel (Citellus tridecemlineatus). J Appl Bacteriol. 1970;33:505-14.

24. Carey HV, Walters WA, Knight R. Seasonal restructuring of the ground squirrel gut microbiota over the annual hibernation cycle. Am J Physiol Regul Integr Comp Physiol. 2013;304:33-42.

25. Gossling J, Loesche W, Nace G. Response of intestinal flora of laboratoryreared leopard frogs (Rana pipiens) to cold and fasting. Appl Environ Microbiol. 1982:44:67-71.

26. Dill-McFarland KA, Neil KL, Zeng A, Sprenger RJ, Kurtz CC, Suen G, et a Hibernation alters the diversity and composition of mucosa-associated bacteria while enhancing antimicrobial defense in the gut of 13-lined ground squirrels. Mol Ecol. 2014;23:4658-69.

27. Starck JM, Beese K. Structural flexibility of the small intestine and liver of garter snakes in response to feeding and fasting. J Exp Biol Med. 2002;205:1377-88

28. Peterson C, Ortega J, Park SH, Hanning I, Hill J, Beaupre S. Gastrointestinal microbes do not influence digestive efficiency in African house snakes (Boaedon fuliginosus). NM: American Society of Ichthyologists and Herpetologists. Albuquerque; 2013. p. 10-5.

29. Heselmans M, Reid G, Akkermans LMA, Savekkoul H, Timmerman H, Rombouts FM. Gut flora in health and disease: potential role of probiotics. Curr Issues Intest Microbiol. 2004;6:1-8.

30. Padilha MTS, Licois D, Gidenne T, Carré B. Caecal microbiota and fermentation pattern in exclusively milk-fed young rabbits. Reprod Nutr Dev. 1999;39:223-30.

31. Kohl KD, Cary TL, Karasov WH, Dearing MD. Restructuring of the amphibian gut microbiota through metamorphosis. Environ Microbiol Rep. 2013:5:899-903.

32. Tetlock A, Yost CK, Stavrinides J, Manzon RG. Changes in the gut microbiome of the sea lamprey during metamorphosis. Appl Environ Microbiol. 2012;78:7638-44.

33. Wang Y, Gilbreath III TM, Kukutla P, Yang G, Xu J. Dynamic gut microbiome across life history of the Malaria mosquito Anopheles gambiae in Kenya. PLoS One. 2011;6:e24767. doi:10.1371/journal.pone.0024767.

34. Muller HE, Pinus M, Schmidt U. Aeromonas hydrophila as a normal intestina bacterium of the vampire bat (Desmodus rotundus). Zentralblatt fur Veterinarmedizin. 1980:27(5):419-424.

35. Boekhorst J, Siezen RJ, Zwahlen MC, Vilanova D, Pridmore RD, Mercenier A, et al. The complete genomes of Lactobacillus plantarum and Lactobacillus johnsonii reveal extensive differences in chromosome organization and gene content. Microbiology. 2004;150:3601-11.

36. Abada EA, Sung H, Dwivedi M, Park B-J, Lee S-K, Ahnn J. C. elegans behavior of preference choice on bacterial food. Mol Cell. 2009;28:209-13.

37. Min KT, Benzer S. Wolbachia, normally a symbiont of Drosophila, can be virulent, causing degeneration and early death. Proc Natl Acad Sci USA. 1997;94:10792-6.

38. Zhang Y, Xie Y, Berglund ED, Coate KC, He T, Katafuchi T, et al. The starvation hormone, fibroblast growth factor-21, extends lifespan in mice. Elife. 2012;1, e00065.

39. McDonald P, Maizi BM, Arking R. Chemical regulation of mid- and late-life longevities in Drosophila. Exp Gerontol. 2013:48:240-9.

40. Patterson J, Burkholder K. Application of prebiotics and probiotics in poultry production. Poultry Sci. 2003:82:627-31.

41. Callaway TR, Edrington TS, Anderson RC, Harvey RB, Genovese KJ, Kennedy CN, et al. Probiotics, prebiotics and competitive exclusion for prophylaxis against bacterial disease. Anim Health Res Rev. 2008;9:217-25. 
42. Shirkey TW, Siggers RH, Goldade BG, Marshall JK, Drew MD, Laarveld B, et al. Effects of commensal bacteria on intestinal morphology and expression of proinflammatory cytokines in the gnotobiotic pig. Exp Biol Med (Maywood). 2006:231:1333-45.

43. Higgins JP, Higgins SE, Vicente JL, Wolfenden AD, Tellez G, Hargis BM. Temporal effects of lactic acid bacteria probiotic culture on Salmonella in neonatal broilers. Poult Sci. 2002;86:1662-6.

44. Summers M. Energy metabolism in the broiler chick. Ontario, Canada: PhD Thesis. University of Guelph; 1991.

45. Cant JP, Mcbride BW, Croom Jr WJ. The regulation of intestinal metabolism and its impact on whole animal energetics. J Anim Sci. 1996;74:2541-53.

46. Karimi Torshizi MA, Moghaddam AR, Rahimi S, Mojgani N. Assessing the effect of administering probiotics in water or as a feed supplement on broiler performance and immune response. Br Poult Sci. 2010;51:178-84.

47. Richards JD, Gong J, De Lange CFM. The gastrointestinal microbiota and its role in monogastric nutrition and health with an emphasis on pigs: current understanding, possible modulations, and new technologies for ecological studies. Canadian J Anim Sci. 2005;85:421-35.

48. Macpherson AJ, Harris N. Interactions between commensal intestinal bacteria and the immune system. Science. 2004:4:478-85.

49. Lauzon CR, Sjogren RE, Wright SE, Prokopy RJ. Attraction of Rhagoletis pomonella (Diptera: Tephritidae) flies to odor of bacteria: apparent confinement to specialized members of Enterobacteriaceae. Environ Entomol. 1998;27:853-7.

50. Dillon RJ, Dillon VM. The gut bacteria of insects: nonpathogenic interactions. Annu Rev of Entomol. 2004;49:71-92.

51. Rosengaus R, Zecher CN, Schultheis KF, Brucker RM, Bordenstein SR. Disruption of the termite gut microbiota and its prolonged consequences for fitness. Appl Environ Microbiol. 2011;77:4303-12.

52. Dai Z, Wu Z, Hang S, Zhu W, Wu G. Amino acid metabolism in intestinal bacteria and its potential implications for mammalian reproduction. Mol Hum Reprod. 2015;21:389-409.

53. Pitta DW, Kumar S, Vecchiarelli B, Shirley DJ, Bittinger K, Baker LD, et al. Temporal dynamics in the ruminal microbiome of dairy cows during the transition period. J Anim Sci. 2014;92:4014-22.

54. Li X, Bazer FW, Johnson GA, Burghardt RC, Frank JW, Dai Z, et al. Dietary supplementation with L-arginine between days 14 and 25 of gestation enhances embryonic development and survival in gilts. Amino Acids. 2014;46:375-84.

55. Buffie CG, Pamer EG. Microbiota-mediated colonization resistance against intestinal pathogens. Nat Rev Immunol. 2013;13:790-801.

56. Stecher B, Robbiani R, Walker AW, Westendorf AM, Barthel M, Kremer M, et al. Salmonella enterica serovar typhimurium exploits inflammation to compete with the intestinal microbiota. PLoS Biol. 2007:5:2177-89.

57. Winter SE, Thiennimitr P, Winter MG, Butler PB, Huseby DL, Crawford RW, et al. Gut inflammation provides a respiratory electron acceptor for Salmonella. Nature. 2010;467:426-9.

58. Diaz MA, Bik EM, Carlin KP, Venn-Watson SK, Jensen ED, Jones SE, et al. Identification of Lactobacillus strains with probiotic features from the bottlenose dolphin (Tursiops truncatus). J Appl Micro. 2013;115:1037-51.

59. Watanabe K, Abe K, Sato M. Biological control of an insect pest by gut colonizing Enterobacter cloacae transformed with ice nucleation gene. J Appl Microbiol. 2000;88:90-7.

60. Beard CB, Cordon-Rosales C, Durvasula RV. Bacterial symbionts of the Triatominae and their potential use in control of Chagas disease transmission 1. Annu Rev Entomol. 2002;47:123-41.

61. Stevens CE, Hume ID. Comparative physiology of the vertebrate digestive system. Cambridge University, 1995

62. Stevens CE, Hume ID. Microbial fermentation and synthesis of nutrients, and the absorption of end productseds. In: Comparitive Physiology of the Vertebrate Disgestive System. Cambridge, UK: Cambridge University Press; 1995. p. 188-203.

63. Logan M. Evidence for the occurrence of rumination-like behavior, or merycism, in the koala (Phascolarctos cinereus, goldfuss). J Zool. 2001;255:83-7.

64. Pope PB, Totsika M, De Carcer DA, Schembri MA, Morrison M. Muramidases found in the foregut microbiome of the tammar wallaby can direct cell aggregation and biofilm formation. ISME J. 2011;5:341-50.

65. Evans PN, Hinds LA, Sly LI, McSweeney CS, Morrison M, Wright AD. Community composition and density of methanogens in the foregut of the tammar wallaby (Macropus eugenii). Appl Environ Microbiol. 2009;75:2598-602
66. Distel DL, Morrill W, MacLaren-Toussaint N, Franks D, Waterbury J. Teredinibacter turnerae gen. nov., sp. nov., a dinitrogen-fixing, cellulolytic, endosymbiotic gamma-proteobacterium isolated from the gills of wood-boring molluscs (Bivalvia: Teredinidae). Int J Syst Evol Microbiol. 2002;52:2261-9.

67. Yang JC, Madupu R, Durkin AS, Ekborg NA, Pedamallu CS, Hostetler JB, et al. The complete genome of Teredinibacter turnerae T7901: an intracellular endosymbiont of marine wood-boring bivalves (shipworms). PLoS One. 2009;4, e6085.

68. Boucias DG, Cai $Y$, Sun $Y$, Lietze VU, Sen R, Raychoudhury $R$, et al. The hindgut lumen prokaryotic microbiota of the termite Reticulitermes flavipes and its responses to dietary lignocellulose composition. Mol Ecol. 2013;22:1836-53. doi:10.1111/mec.12230.

69. Raina AK, Park YI, Lax A. Defaunation leads to cannibalism in primary reproductives of the Formosan subterranean termite, Coptotermes formosanus (Isoptera:Rhinotermitidae). Ann Entomol Soc Am. 2004;97:753-6.

70. Buczkowski G, Wang C, Bennett G. Immunomarking reveals food flow and feeding relationships in the eastern subterranean termite, Reticulitermes flavipes (Kollar). Environ Entomol. 2007;36:173-82.

71. Raggi L, Schubots F, Hinrichs KU, Dubilier N, Petersen JM. Bacterial symbionts of Bathymodiolus mussels and Escarpia tubeworms from Chapopote, an asphalt seep in the Southern Gulf of Mexico. Env Microbiol. 2013;15:1969-87.

72. Giles EC, Kamke J, Moitinho-Silva L, Taylor MW, Hentschel U, Ravasi T, et al. Bacterial community profiles in low microbial abundance sponges. FEMS Microbiol Ecol. 2013;83:232-41.

73. Webster NS, Taylor MW, Bechnam F, Lücker S, Rattei T, Whalan S, et al. Deep sequencing reveals exceptional diversity and modes of transmission for bacterial sponge symbionts. Env Microbiol. 2010;12:2070-82.

74. Glad T, Bernhardsen P, Nielsen KM, Brusetti L, Andersen M, Aars J, et al. Bacterial diversity in faeces from polar bear (Ursus maritimus) in arctic Svalbard. BMC Microbiol. 2010;10:1-10.

75. Ogawa $\mathrm{G}$, Ishida $\mathrm{M}$, Kato $\mathrm{H}$, Fujise $\mathrm{Y}$, Uranothe $\mathrm{N}$. Identification of facultative anaerobic bacteria isolated from intestine of the minke whale Balaenoptera acutorostrata by 16S rRNA sequencing analysis. Fish Sci. 2010;76:177-81.

76. Turnbaugh P, Ley R, Mahowald MA, Magrini V, Mardis ER, Gordon J. An obesity-associated gut microbiome with increased capacity for energy harvest. Science. 2006;444:1027-31.

77. Qu A, Brulc JM, Wilson MK, Law BF, Theoret JR, Joens LA, et al. Comparative metagenomics reveals host specific metavirulomes and horizontal gene transfer elements in the chicken cecum microbiome. PLoS ONE. 2008;3:e2945

78. Brulc JM, Antonopoulos DA, Miller ME, Wilson MK, Yannarell AC, Dinsdaled EA et al. Gene-centric metagenomics of the fiber-adherent bovine rumen microbiome reveals forage specific glycoside hydrolases. Proc Natl Acad Sci USA. 2009:106:1948-53.

79. Godoy-Vitorino F, Goldfarb KC, Karaoz U, Leal S, Garcia-Amado MA, Hugenholtz $\mathrm{P}$, et al. Comparative analyses of foregut and hindgut bacterial communities in hoatzins and cows. ISME J. 2012;6:531-41.

80. Leser T, Amenuvor J, Jensen T, Lindecrona R, Boye M, Møller K. Culture independent analysis of gut bacteria: the pig gastrointestinal tract revisited. Appl Environ Micro. 2002;2:673-90.

81. Lamendella R, Santo Domingo JW, Ghosh S, Martinson J, Oerther DB. Comparative fecal metagenomics unveils unique functional capacity of the swine gut. BMC Microbiol. 2011;11:103.

82. Nikoh N, Hosokawa T, Oshima K, Hattori M, Fukatsu T. Reductive evolution of bacterial genome in insect gut environment. Genome Biol Evol. 2011;3:702-14.

83. Eichler S, Schaub G. Development of symbionts in triatomine bugs and the effects of infections with trypanosomatids. Exp Parasitol. 2002;100:17-27.

84. Crotti E, Rizzi A, Chouaia B, Ricci I, Favia G, Alma A, et al. Acetic acid bacteria, newly emerging symbionts of insects. Appl Environ Microbiol. 2010;76:6963-70

85. Robinson CJ, Schloss P, Ramos Y, Raffa K, Handelsman J. Robustness of the bacterial community in the cabbage white butterfly larval midgut. Microb Ecol. 2010;59:199-211.

86. Storelli G, Defanque A, Erkosar B, Hols P, Royet J, Leulier F. Lactobacillus plantarum promotes Drosophila systemic growth by modulating hormonal signals through TOR-dependent nutrient sensing. Cell Metab. 2011;14:403-14. 
87. Allison MJ, Mayberry WR, McSweney CS, Stahl DA. Synergistes jonesii gen. nov., sp. nov.: a rumen bacterium that degrades toxic pyridine diols. Syst Appl Microbiol. 1992;1992(15):522-9.

88. Wallace RJ. Gut microbiology: broad genetic diversity, yet specific metabolic niches. Animal. 2008;2:661-8.

89. Dailey RN, Montgomery DL, Siemion R, Vasquez M, Raisbeck MF. Toxicity of the lichen secondary metabolite usnic acid in domestic sheep. Vet Pathol. 2008;45:19-25.

90. Sundset MA, Kohn A, Mathiesen SD, Praesteng KE. Eubacterium rangiferina, a novel usnic acid-resistant bacterium from the reindeer rumen. Naturwissenschaften. 2008;95:741-9.

91. Smith AH, Zoetendal E, Mackie RI. Bacterial mechanisms to overcome inhibitory effects of dietary tannins. Microb Ecol. 2005;50:197-205.

92. Pinus M, Müller HE. Enterobacteria of bats (Chiroptera). Zentralbl Bakteriol A. 1980;247:315-22.

93. Pope PB, Denman SF, Jones M, Tringe SG, Barry K, Malfatti SA, et al. Adaptation to herbivory by the tammar wallaby includes bacterial and glycoside hydrolase profiles different from other herbivores. PNAS. 2010;107:14793-8.

94. Lu J, Santo Domingo JW, Lamendella R, Edge T, Hill S. Phylogenetic diversity and molecular detection of gull feces. Apply Environ Microbiol. 2008;74:3969-76.

95. Zhu L, Wu Q, Dai J, Zhang S, Weit F. Evidence of cellulose metabolism by the giant panda gut microbiota. PNAS. 2011;108:17714-9.

96. Endo A, Endo-Futagama Y, Dicks LMT. Diversity of Lactobacillus and Bifidobacterium in feces of herbivores, omnivores and carnivores. Anaerobe. 2010;2010(16):590-6.

97. Matsui H, Kato Y, Chikaraishi T, Moritani M, Ban-Tokuda T, Wakita M. Microbial diversity in ostrich ceca as revealed by 165 ribosomal RNA gene clone library and detection of novel Fibrobacter species. Anaerobe. 2010;16:83-93.

98. Wu SG, Wang G, Angert ER, Wang W, Li W, Zou H. Composition, diversity, and origin of the bacterial community in grass carp intestine. PLoS One. 2012; $7:$ :30440.

99. Flint HJ, Bayer EA. Plant cell wall breakdown by anaerobic microorganism from the mammalian digestive tract. Ann NY Acad Sci. 2008;1125:280-8.

100. Hong P-Y, Wheeler E, Cann IKO, Mackie RI. Phylogenetic analysis of the fecal microbial community in herbivorous land and marine iguanas of the Galapagos Islands using 165 RNA-based pyrosequencing. ISME J. 2011;5:1461-70.

101. Pryor GS. Anaerobic bacteria isolated from the gastrointestinal tracts of bullfrog tadpoles (Rana catesbeiana). Herpetol Conserv Biol. 2008;3:176-81.

\section{Submit your next manuscript to BioMed Central and take full advantage of:}

- Convenient online submission

- Thorough peer review

- No space constraints or color figure charges

- Immediate publication on acceptance

- Inclusion in PubMed, CAS, Scopus and Google Scholar

- Research which is freely available for redistribution 